\title{
EL RECLUTAMIENTO Y ENTRENAMIENTO PARA LA CONTRAOFENSIVA (1978-1980). REFLEXIONES SOBRE LA POLÍTICA Y LA VIOLENCIA EN LOS ÚLTIMOS AÑOS DE MONTONEROS
}

\author{
Recruiting and training for the counter-offensive (1978-1980). Reflections on \\ politics and violence on the last years of montoneros.
}

Hernán Eduardo Confino*

https://orcid.org/0000-0003-0852-8224

\section{Resumen}

A partir de la reconstrucción del reclutamiento y entrenamiento que hizo Montoneros para el desarrollo de la Contraofensiva, este artículo reflexiona de un modo más general sobre la relación entre política y violencia que animó los últimos años de la organización. Para ello, se vale del testimonio de los protagonistas y de los documentos partidarios de Montoneros y de los servicios de inteligencia de la dictadura. El objetivo es estudiar los sentidos políticos que derivan del modo de incorporación y el tipo de preparación que privilegió la organización para con sus militantes. Pensado como un dispositivo disciplinador y homogeneizador, el entrenamiento trascendió por mucho la práctica militar. Por tanto, se hipotetiza como improductiva la antinomia entre política y violencia que muchos trabajos han privilegiado en el estudio de la trayectoria de Montoneros.

$<$ Montoneros $><$ Contraofensiva Estratégica $><$ Política $><$ Violencia $>$

\begin{abstract}
This article traces the recruiting and training process carried out by Montoneros to develop its Counter-Offensive. Hence, it provides a wider view on the relationship between politics and violence during the last years of the organization. For this purpose, testimonies, party documents from Montoneros and intelligence briefs produced by the dictatorship are analyzed. The aim is to study the political meanings that stem from the mode of admission and the type of training of militants to which the organization gave priority. As a disciplinary and homogenizing device, training went far beyond military practice. In this light, the dichotomy between politics and violence, which many studies have privileged while looking at the trajectory of Montoneros, is here considered unproductive.
\end{abstract}

$<$ Montoneros $><$ Strategic Counteroffensive $><$ Politics $><$ Violenc $>$

Recibido: 10/07/2019

Aceptado: 03/09/2019

\footnotetext{
* Becario Posdoctoral del Consejo Nacional de Investigaciones Científicas y Técnicas (CONICET) con sede en la Universidad Nacional de General Sarmiento (UNGS), Argentina. hconfino@gmail.com
} 
Confino. El reclutamiento y entrenamiento para la contraofensiva (1978-1980). Reflexiones sobre la política y...

\section{Introducción}

Entre las miradas sobre los últimos años de la organización Montoneros sobresale aquella que, a través de modelos como el "desvío", el "espejo" o el "quiebre" (Slipak, 2017) ha explicado la trayectoria de la organización como un movimiento unidireccional desde las lógicas políticas a las militares, entendidas como su negación. Para estas interpretaciones, hacia el final de la década de 1970 no habría habido política al interior de la agrupación. En todo caso, y a partir de que la dictadura tomó el poder del Estado (1976-1983), Montoneros se habría regido exclusivamente, o habría sido capturado, por las lógicas de la violencia o la guerra (Calveiro, 2005; Gasparini, 2005; Gillespie, 1998 y Vezzetti, 2009). Esta sentencia tiene una premisa que me interesaría discutir en este artículo. La consideración de la política y la violencia (o la guerra) como antagónicas y excluyentes. Desde una concepción de la política más cercana a la ausencia de conflicto - vinculada con los imperativos morales de la democracia nacida en 1983 o con las necesidades autocríticas de los ex militantes (Acha, 2010 y Oberti \& Pittaluga, 2006) que a la regulación parcial y cambiante del mismo, estas visiones han construido la trayectoria montonera en dos grandes etapas. Desde sus inicios y hasta la autoclandestinización de 1974 o, también, hasta los primeros meses de 1976, Montoneros habría sido un complejo entramado político-militar que habría patrocinado políticas legales y multitudinarias, y otras militares y clandestinas. Luego, habría eliminado la política, reduciéndola a la violencia. La Contraofensiva Estratégica, iniciada en octubre de 1978, no habría sido más que la ejemplificación -lógica, cronológica y descarnadade este modelo (Calveiro, 2005 y Gillespie, 1998).

En las páginas que siguen propondré que, a contracorriente de lo que plantean estas lecturas, durante los últimos años de Montoneros hubo política. Una política que estuvo atravesada por un imaginario bélico y se apoyó en los métodos militares. Una política, también, cuyo significado no fue estático y provocó disputas y debates entre los militantes, por los menos desde el exilio orgánico de septiembre de 1976 (Confino, 2018a). En este trabajo intento evitar la falsa antinomia entre política y violencia, más esencialista que histórica y por eso improductiva para estudiar una organización político-militar que, desde sus comienzos, las pensó fusionadas (Slipak, 2015).

Para dar cuenta de la imbricación entre política y violencia en Montoneros reconstruiré la convocatoria y el entrenamiento que diagramó la organización una vez iniciada la Contraofensiva, en octubre de 1978. Aprobado el "retorno organizado", la agrupación propagó el llamado y estructuró el adiestramiento que recibirían los militantes que habían escapado de la represión de la dictadura y vivían en el extranjero. En la modalidad de la convocatoria y el contenido del entrenamiento se pueden precisar los sentidos políticos que Montoneros refrendaba durante los últimos años de la década de 1970. Estos sentidos incluían - pero excedían- la práctica armada de la política.

Para los militantes que habían decidido regresar, los dos principales puntos de incorporación a la Contraofensiva se ubicaron en la Ciudad de México y en Madrid, los centros de mayor desarrollo político montonero en el exterior (Acha, 2006; Robledo, 2018 y Yankelevich, 2010). No obstante, la convocatoria también fue extendida a otros 
espacios en el extranjero, desde América del Norte hasta Escandinavia, como resultado de la dispersión geográfica que habían sufrido los exiliados argentinos (Astiz, 2005; Falcone, 2001 y Zuker, 2010).

Desde el momento en que fue lanzado, el anuncio encontró resistencia en numerosos sectores del exilio que no quisieron participar y que, además, condenaron la persistencia militar de la política de Montoneros. ${ }^{1}$ Quienes se sumaron a la Contraofensiva, en cambio, lo hicieron desde una concepción distinta de la que comenzaba a nutrir el pensamiento de gran parte de los argentinos que estaban en el exterior, vinculada al "paradigma humanitario" constituido por la denuncia de los crímenes de la dictadura y la defensa de los derechos humanos en distintos foros internacionales (Franco, 2008; Jensen, 2007 y 2010; Yankelevich, 2010). Si bien, como precisé en trabajos previos, un conjunto de militantes montoneros también había centrado su actividad en la denuncia de la represión dictatorial en el extranjero, su pertenencia a la organización indicaba al mismo tiempo su conformidad con los métodos militares (Confino, 2018c).

La experiencia de los militantes que participaron de la Contraofensiva permite matizar, a su vez, la asociación dominante en la bibliografía especializada entre exilio y política humanitaria, habilitando así la posibilidad de analizar las historias de quienes, aun en el exterior, todavía se sentían interpelados por la posibilidad del cambio revolucionario. No obstante esta afinidad de pensamiento, conformaban un grupo heterogéneo y con trayectorias diversas que incluían a menudo, además del exilio, la cárcel legal y la detención ilegal. En el exterior, muchos habían participado de circuitos de sociabilidad diferentes y mientras que algunos habían conservado el vínculo orgánico con Montoneros, otros realizaban su primer acercamiento con motivo de la Contraofensiva. En este marco, la intención de los dirigentes de la organización era que el reclutamiento y, sobre todo, el adiestramiento produjeran una uniformidad de concepción y ejecución en los militantes que iban a regresar a la Argentina dictatorial.

En este artículo reconstruyo la convocatoria y el entrenamiento desarrollados por Montoneros previo al retorno al país. Indago las prácticas de reclutamiento y preparación que contempló la Contraofensiva y analizo algunas experiencias militantes durante ese proceso: ¿Cuál fue la amplitud de la convocatoria? ¿A quiénes estuvo dirigida? ¿Cuáles fueron las funciones primordiales del entrenamiento? ¿Qué trayectorias militantes reunió? ¿Qué lugar ocupó la experiencia del exilio? ¿Qué tipo de preparación se privilegió? ¿Qué aspectos se dejaron de lado? ¿Qué ideas tenía la organización sobre estas actividades? ¿Cómo las apropiaron los participantes?

Los entrenamientos llevados a cabo en México, España, El Líbano y Siria durante 1979 fueron establecidos por Montoneros como un dispositivo homogeneizador y disciplinador para los militantes (Agamben, 2011). Dicho dispositivo debía restituir la historia e ideología montonera para quienes no habían transitado la experiencia de

\footnotetext{
Algunos de estos cuestionamientos serían estructurantes, entre otras intervenciones, de la revista Controversia para un examen de la realidad argentina, publicada desde octubre de 1979 hasta agosto de 1981 por argentinos exiliados en México -varios con pasado militante en Montoneros-. Al respecto véase Bernetti y Giardinelli, 2014; Gago, 2012, Ponza, 2012 y Vezzetti, 2009.
} 
Confino. El reclutamiento y entrenamiento para la contraofensiva (1978-1980). Reflexiones sobre la política y...

militancia dentro de la organización o para aquellos que, debido a la cárcel, el secuestro o el exilio, habían quedado al margen. Por eso es relevante analizar las características del lazo que intentó fundar la experiencia en común diseñada por la organización, a partir de la reconstrucción de sus actividades principales, sus lugares de realización y sus participantes. Si bien el foco está puesto en el reclutamiento y entrenamiento previos a la primera Contraofensiva, se consideran también testimonios y vivencias referidas a la segunda, producida en simultáneo con el regreso de 1979. Esto se debe a que, en líneas generales, ambos momentos enseñan la misma intención homogeneizadora y disciplinadora de parte de Montoneros hacia sus integrantes. ${ }^{2}$ Finalmente, es en los intersticios entre las directivas de la organización y las apropiaciones de los militantes donde este trabajo busca algunas claves explicativas de la Contraofensiva y, de modo más general, analiza la compleja imbricación entre política y violencia, central en el imaginario y las prácticas de Montoneros.

\section{El combate contra la dispersión}

Con el propósito del reingreso al país, Montoneros organizó a los militantes reclutados en pequeñas células incomunicadas entre sí, divididas según el tipo de participación que les sería asignada. Las Tropas Especiales de Agitación (TEA), al mando de Horacio Mendizábal, deberían realizar interferencias televisivas con proclamas apoyando a los conflictos sindicales que se preveían como el principal factor de desestabilización del gobierno militar. Las Tropas Especiales de Infantería (TEI), comandadas por Raúl Yäger, tendrían a su cargo los atentados militares sobre el equipo económico de Martínez de Hoz. Los blancos escogidos por Montoneros fueron Juan Alemann, Secretario de Hacienda, Guillermo Klein, Secretario de Programación y Coordinación Económica, y Francisco Soldati, director del Banco de Crédito Argentino (Larraquy, 2006; Robledo, 2018).

Una gran cantidad de los participantes de las TEA y las TEI fue enrolada y entrenada en el extranjero entre fines de 1978 y principios de 1979. Sin embargo, no todos ellos habían vivido en el exterior. Este es el caso de un grupo de montoneros que, a pesar de haber perdido el contacto con la organización, había continuado su militancia en la zona sur del conurbano bonaerense en los momentos más represivos del terror estatal. Luego de lograr el "reenganche", los antiguos miembros de la "Regional Columna Sur" fueron convocados al extranjero para recibir los cursos de preparación para la Contraofensiva y volvieron a la Argentina en julio de 1979 conformando las TEA-Sur (Confino, 2018b).

\footnotetext{
2 De acuerdo al testimonio de H. N. -integrante de un "grupo de logística" de Montoneros entre 1978 y 1980 la idea de la organización era instruir a todos sus potenciales militantes en el exterior, independientemente de que tuvieran tareas programadas en Argentina o no (H.N., entrevista con el autor, Buenos Aires, 31 de octubre de 2016). Así, la segunda oleada de 1980 se realizó en consonancia con los principales lineamientos del primer retorno, sin alterar las prescripciones para el entrenamiento de los militantes.
} 
Meses antes, había comenzado la convocatoria. En el primer número de la revista Vencer, órgano de prensa del Movimiento Peronista Montonero (MPM), se publicaba el llamado para alistarse a la Contraofensiva:

El Movimiento Peronista Montonero entiende que la integración a ese proceso de resistencia a la dictadura, de aportes humanos capacitados que actualmente están en el exterior, ayudará grandemente a una definición adversa a la dictadura que a todos nos oprime y perjudica. Cada compatriota que decida volver a la Argentina para sumar su esfuerzo personal de acuerdo a sus inclinaciones naturales, su creatividad y sus preferencias acerca de las modalidades y variaciones de la resistencia popular, será un valioso colaborador de la causa del pueblo y de la autodeterminación nacional, en el lanzamiento de la contraofensiva [...] EL MOVIMIENTO PERONISTA MONTONERO convoca a la colonia de exiliados y emigrados a VOLVER a Argentina para incorporarse subordinadamente a la ejecución de [...] actividades (Baschetti, 2014, pp. 107-108).

El documento del MPM era el puntapié de la Contraofensiva y, tal como plantea una de sus destinatarias, trascendió a los desterrados peronistas. Exiliada en Madrid, H.D. ${ }^{3}$ recuerda que la convocatoria "se larga [...] de una forma pública en un local muy grande que tiene el Partido Comunista" en la capital española. A esa reunión informativa de febrero de 1979, Montoneros invitó "no solamente al exilio peronista, sino a todos". ${ }^{5}$ La organización buscaba interpelar a la totalidad de los emigrados argentinos que quisieran enfrentarse a la dictadura. Por ese motivo, la convocatoria del MPM estaba dirigida a los "compañeros y compatriotas". No importaba tanto la filiación peronista de los posibles receptores del mensaje, sino el origen nacional y la intención de sumarse a la alternativa montonera. ${ }^{6}$ No era necesario haber tenido un pasado peronista para integrar la Contraofensiva. Pero sí lo era, en caso de participar, subordinarse a las formas pensadas por Montoneros para hacerlo.

Las sedes principales del reclutamiento fueron Madrid y Ciudad de México, pero no fueron las únicas. Hubo militantes montoneros invitando al regreso en todos

\footnotetext{
3 A los efectos de este escrito, se resguardan las identidades de los entrevistados y se explicitan, en cambio, las de los protagonistas más reconocidos y públicos y también las de aquellos que fueron asesinados y desaparecidos.

4 H.D., entrevista con el autor, Rosario, 25 de abril de 2015. H.D. comenzó su militancia en la UES de Rosario y, luego de su detención, consiguió el derecho a opción en 1978 y se exilió en Madrid. Allí se integró como "miliciana" TEI a los grupos de la Contraofensiva.

5 H. D., entrevista con el autor.

${ }^{6}$ La literatura testimonial y periodística sobre la Contraofensiva da cuenta de la incorporación de militantes de otras organizaciones, como el Ejército Revolucionario del Pueblo 22 de agosto o la Organización Comunista de Poder Obrero e, incluso, de algunos militantes sin pasado en otra organización revolucionaria (Astiz, 2005; Larraquy, 2006; Falcone, 2001 y Robledo, 2018).
} 
Confino. El reclutamiento y entrenamiento para la contraofensiva (1978-1980). Reflexiones sobre la política y...

los destinos del exilio argentino. Jorge Falcone (2001, p. 154) ${ }^{7}$, por ejemplo, recuerda que fue convocado durante su exilio en Suecia. Elvio Alberione, participante de la reunión de lanzamiento de la Contraofensiva, propagó las resoluciones del Comité Central por Bolivia, Perú, Venezuela, Panamá y Canadá, entre otros países. ${ }^{8} \mathrm{Al}$ respecto, una constante parecería haberse impuesto en la modalidad de la preparación de los militantes con relación al lugar de incorporación y el tipo de tarea a realizar. Mientras que la gran mayoría de los alistados en Europa, previo paso por Madrid, habría sido adiestrada en Medio Oriente para luego integrarse a las TEI, los reclutados en la Ciudad de México habrían integrado los grupos de propaganda que entrenaron en Cuernavaca y San Miguel de Allende.

Cristina Zuker también asistió a la reunión que Montoneros organizó en suelo español y destaca que "concurrió gran parte de la colonia argentina" (2010, p. 245). Con la presencia de Roberto Perdía -número dos de la organización- como orador estelar, el cónclave finalizó con la invitación a los concurrentes interesados a dejarles sus datos de contacto a la organización. Al respecto, recuerda H.D.:

En esa reunión [...] grande, en la que estuvo [...] Perdía [...] y estaba Bidegain. [...] lo que más se preguntaba era el tema de seguridad. La seguridad como si ya esperáramos, no sé, [...] y eso se largaba público, entonces era como que los militares nos iban a estar esperando. Ahí es cuando decían "sí, pero no", porque una vez que los compañeros se integraban a los grupos de Contraofensiva ahí ya se tomaban todos los recaudos de seguridad y que en ese momento no era ni el momento ni el lugar, que ahí se iba a discutir más privadamente. ${ }^{9}$

B.C. ${ }^{10}$ también participó de la reunión presidida por Perdía en el invierno madrileño de 1979. Evoca un salón repleto, con un estimativo de doscientos asistentes. Desde su llegada al exterior, B.C. se había apartado de Montoneros, lo que explica que aquella mañana no reconociera a la mayoría de las personas que se habían congregado. Luego de identificar a Perdía como el único miembro de la Conducción Nacional que se hizo presente, $\mathrm{BC}$ escuchó su intervención: la dictadura comenzaba a transitar una crisis

7 Falcone comenzó su militancia en la Federación Universitaria de la Revolución Nacional (FURN) en 1970, luego pasó por la Juventud Universitaria Peronista (JUP) entre 1973-1976 y finalmente se integró al Área Federal de Prensa de Montoneros donde, además, fue el último Secretario de Prensa hasta que Firmenich, en 1990, dio libertad de acción a los militantes que aún respondían a su jefatura. Formó parte del retorno en la segunda Contraofensiva.

8 "Y bueno, lo que yo hice en Bolivia, Perú, Venezuela, Panamá, estos eran los lugares donde había compañeros, ah bueno, Canadá (ellos venían a Panamá), fue bajar esta directiva y esta lectura de documento que planteaba las posibilidades de la Contraofensiva y particularmente de golpear sobre el centro de gravedad del proceso, que era la política económica." (Memoria Abierta, testimonio de Elvio Alberione, Buenos Aires y Córdoba, 7 de junio y 4 de agosto de 2008 y 10 de diciembre de 2009).

9 H.D., entrevista con el autor, ob. cit.

${ }^{10}$ B.C. comenzó su militancia en el FURN y luego integró la JUP en La Plata, donde fue secuestrado luego de un operativo de propaganda. Accedió al derecho a opción en 1978 y se exilió en Madrid donde se integró a los grupos de la Contraofensiva para retornar como "miliciano" TEI en 1979. 
que podría ser potenciada a partir del regreso clandestino de los militantes montoneros a la Argentina. Las políticas económicas eran sindicadas como el talón de Aquiles del régimen. El "tren de la victoria" al que convocaba el "comandante montonero"11 interesó a B.C. quien, luego de la reunión, depositó sus datos en una urna y se integró, tiempo después, a los grupos TEI que entrenaron en Madrid y El Líbano. ${ }^{12}$

H.N., por su parte, acabaría integrando en 1979 un grupo que dependía exclusivamente de la Conducción Nacional y estaba encargado de hacer y transportar documentación. Había llegado a París a fines de 1977 junto con su madre, escapando del terrorismo de Estado. Cuando se enteró de la reunión, viajó a Madrid para participar de ella. Una vez allí, lo alarmó la falta de seguridad que rodeó a la convocatoria:

La convocatoria a la Contraofensiva [...] no fue lo más prolijo que se pudo haber hecho [...] Yo estuve ahí. Estaba el Pelado [Perdía], Bidegain. "¿Quién quiere vender helado?" "Yo", "Anotáte y dejá tus datos en la urna". Yo no sé si después hubo un chequeo de esa gente, si la "orga" [Montoneros] lo hizo [...] Igual ya con el lanzamiento de la Contraofensiva, de hecho en la causa judicial estamos viendo los documentos de inteligencia del [Batallón de Inteligencia] 601 y dicen "desde el exterior se preparan así que vamos a alertar las fronteras". Regalados. O sea, vos como ejército revolucionario le estás avisando a tu enemigo "che, ojo que voy a entrar". ${ }^{13}$

La reunión de Madrid tuvo una notable repercusión. Gran parte de los argentinos que estaban viviendo en España -y en otros puntos de Europa- estuvo enterada y, tal vez por ello, las preguntas recurrentes de los presentes aquella mañana de febrero de 1979 giraron en torno a las medidas de seguridad que dispondría Montoneros para proteger a quienes volvieran. El nivel de publicidad del llamado, no obstante, parecía difícil de congeniar con el carácter secreto que necesitaba la maniobra para ser efectiva. Esta tensión, notada por Marina Franco (2008, p. 150) para el caso de los argentinos exiliados en Francia, organizó las primeras inquietudes de los asistentes al encuentro, en un claro síntoma de preocupación por el cuidado de sus vidas.

Luego de depositar los datos en la urna, los interesados accederían a una charla privada con un militante orgánico que les brindaría algunos detalles que, por su carácter reservado, no podían contarse en público. Así le sucedió a B.C. Una semana después del encuentro fue visitado por Jorge Lewinger, uno de los encargados del reclutamiento. Debían acordar los pormenores de su incorporación. B.C. pidió integrar las TEI y se negó a formar parte de las TEA por haber sido detenido en La Plata, en mayo de 1976, haciendo tareas de propaganda: "si volvía, volvía agarrando las armas". ${ }^{14}$ Por su parte, H.D. también fue visitada por Lewinger. En su caso, la integración a las TEI fue

\footnotetext{
${ }^{11}$ Así se titula el libro de Zuker en alusión a la definición de Perdía.

${ }^{12}$ B.C., entrevista con el autor, Buenos Aires, 18 de febrero de 2016.

${ }^{13}$ H.N., ob. cit.

${ }^{14}$ B.C., entrevista con el autor, ob. cit.
} 
Confino. El reclutamiento y entrenamiento para la contraofensiva (1978-1980). Reflexiones sobre la política y...

decisión de Montoneros. Aun así, hubo militantes que, habiendo transcurrido su exilio en Europa, fueron convocados a las TEA, aunque no fue lo más frecuente. ${ }^{15}$ Cristina Zuker (2010, p. 160) escribe que, ante la incorporación de su hermano a la Contraofensiva y estando exiliada en Madrid, barajó la posibilidad de sumarse a las TEA. Los recuerdos y opiniones de los protagonistas, por tanto, permiten dudar de que la totalidad de los reclutados en Europa fuesen mecánicamente incorporados a las TEI mientras que los enrolados en México lo hicieran automáticamente en las TEA. Presumiblemente, los grupos también se armaban obedeciendo a una cuestión geográfica. Era más directo llegar a Medio Oriente -lugar del entrenamiento militar- partiendo de Europa que haciéndolo desde México.

Los requisitos para integrarse a la Contraofensiva descansaron en la voluntad de los militantes de volver al país. Así también lo recuerda Perdía:

Todos estábamos súper ansiosos, no éramos exiliados, no íbamos a esperar que terminara [la dictadura] para volver, no. Éramos los que teníamos que voltear a la dictadura, entonces había una ansiedad muy grande. Y al revés de lo que puede decirse ahora $[\ldots]$ todo el mundo quería venir. Todo el mundo quería volver en principio, la inmensa mayoría y todos sentían la angustia de ya hacer algo. ${ }^{16}$

Para el ex número dos de Montoneros, la predisposición a regresar de los militantes fue un motivo suficiente para la realización de la Contraofensiva. En su visión, los integrantes de la organización tenían el deber de combatir y "voltear" la dictadura. En esta apreciación, el contexto político del régimen queda relegado a un segundo plano. "Todo el mundo quería venir" porque "todos sentían la angustia de ya hacer algo" es una expresión que hace más hincapié en el estado emocional de los exiliados que en la posibilidad política real de oposición a la dictadura. Incluso contemplando la ansiedad que Perdía atribuye a los militantes en el extranjero, las preguntas que hicieron sobre la discreción de la maniobra y la seguridad personal en la reunión española permiten tomar distancia del contenido de su testimonio. Si bien es indudable que el deseo de regresar al país fue una razón contundente para integrarse a la Contraofensiva, algunos militantes también mostraron dudas e inseguridades. Seguramente, el proceso de incorporación no haya sido tan lineal como lo remarca Perdía, interesado en desestimar la crítica de que quienes retornaron habrían sido obligados o engañados por los dirigentes montoneros. ${ }^{17}$

No obstante, y más allá de las opiniones que circulaban dentro del "montonerismo", entre los exiliados las visiones distaron de ser unánimes. Juan Salinas,

${ }^{15}$ H.D., entrevista con el autor, ob. cit.

${ }^{16}$ Roberto Perdía, entrevista con el autor, City Bell, 14 de diciembre de 2016.

${ }^{17} \mathrm{La}$ interpretación centrada en la idea de "animémonos y vayan" que ha cristalizado en la memoria que versa sobre la Contraofensiva tiene su mayor exponente en el trabajo de Gasparini (2005). Aun así, una mirada a la generalidad del proceso demuestra que todos los militantes que participaron de la maniobra tuvieron un margen de elección para no hacerlo. Paradójicamente, la frase fue acuñada por la propia Conducción Nacional para impugnar la actitud de los disidentes durante el debate partidario que se produjo luego de la Contraofensiva de 1979 (Confino, 2018c). 
ex montonero radicado en España, rechazó enérgicamente el llamado a integrar los contingentes de la Contraofensiva:

De la Contraofensiva hay un hijoputa (sic) que no lo quiero ni mencionar que anda dando vueltas por ahí. Yo llego a Madrid a verlo al "Pato Varieté [Zuker]" y a otros compañeros que están vivos y que ahora [2002] son funcionarios del gobierno de la Ciudad y me acuerdo que viene uno y me dice: "Pájaro, tenés que volver, porque hay que volver a luchar a la Argentina", y yo le digo: "No, no, yo me fui de la 'orga' [Montoneros], no estoy más". "Pero no importa, tenés que ingresar para volver a la Contraofensiva", y no volvió, este hijo de puta no volvió, mandó como a veinticinco al frente. ${ }^{18}$

La desvinculación de Salinas al llegar al exilio no fue un impedimento para ser uno de los destinatarios de la amplia convocatoria de Montoneros. Al mismo tiempo, su impugnación del llamado, en su recuerdo del 2002, va más allá de la política y se vincula con la dimensión ética, al sostener que quien había convocado al retorno no había vuelto. Detrás de sus argumentos, presumiblemente, resuenan los de muchos exiliados que no comulgaban con la propuesta montonera y se inclinaban por otras modalidades de acción política en contra del régimen militar. Emprendimientos editoriales como Controversia para el examen de la realidad argentina, nacida de las inquietudes de los exiliados argentinos en México durante 1979, se encargarían de pensar y discutir nuevas modalidades de oposición, revalorizando la democracia como condición central de la propuesta futura (Confino, 2018c).

En concreto, tanto H.D. como B.C., luego de haber brindado sus datos a la organización, fueron contactados y ultimaron los detalles de su incorporación a la Contraofensiva. En una reunión con Lewinger, accedieron a la lectura pormenorizada que la cúpula de Montoneros hacía sobre la situación política argentina, que no había sido explicitada en la reunión madrileña:

Viene [Jorge] "Josecito" Lewinger, me explica lo mismo, nada más que bueno, con más detalles, de cuáles eran las fábricas que estaban en conflicto, de cuántos compañeros resistiendo o que nosotros teníamos posibilidades. Lo que no se dijo en la reunión grande era que teníamos que volver porque, digamos, porque estaba desapareciendo la organización. Montoneros dejaba de existir. Y dejaba de existir no tanto por las caídas, por las desapariciones, sino por la falta de política y de acciones. O sea, Montoneros ya no estaba haciendo las acciones ni nada, quedaban pocos compañeros, entonces, peligraba la vida de la organización como estaba conformada. ${ }^{19}$

\footnotetext{
${ }^{18}$ Memoria Abierta, Testimonio de Juan Salinas, Buenos Aires, 6 y 11 de diciembre de 2002.

${ }^{19}$ H.D., entrevista con el autor, ob. cit.
} 
Más allá de la lectura política que enmarcaba el retorno, es destacable la "nueva" justificación que, de acuerdo con H.D., había planteado Lewinger sobre la necesidad de la Contraofensiva: la supervivencia de Montoneros. Desde que sus militantes se habían escapado de la Argentina por la represión dictatorial, la actividad política de la organización había quedado ceñida principalmente al extranjero. Para que Montoneros "no dejara de existir" era necesario el regreso al país. Su desaparición, argumenta H.D., no estaba relacionada con la represión padecida sino, sobre todo, con su principal consecuencia: las dificultades para continuar con el proyecto en la Argentina. Quedaba establecida, de este modo, una intrincada relación: era necesario poner en riesgo la vida de los militantes para salvaguardar la vida de la organización.

Después de la reunión privada, los militantes reclutados debieron armar una coartada que explicase a sus familiares la ausencia prolongada de sus hogares europeos. No podrían contactarse con ellos durante el tiempo que durara el entrenamiento y el retorno al país. Nadie debería enterarse de la decisión que habían tomado. Después, sobrevendría la cita en Madrid a la que acudirían alistándose definitivamente para el retorno. Los esperaba más de un mes de formación política en un caserón de las afueras de la capital española y un curso de preparación estrictamente militar del otro lado del Mar Mediterráneo, en El Líbano y Siria.

Además de Madrid, el otro gran centro de reclutamiento estuvo en la Ciudad de México. Así también lo señaló la inteligencia del gobierno de facto, que poseía vasta información sobre las actividades de Montoneros en el exterior. Los datos de los servicios de inteligencia de la dictadura obedecían a la infiltración del personal militar dentro la organización y también a la información obtenida a través de los tormentos aplicados a los militantes secuestrados:

Existe [en Ciudad de México] un centro de reclutamiento a cargo del DT [Delincuente terrorista] [tachado en el original] operando fundamentalmente sobre argentinos que salieron "opcionados" del país, quienes sometidos previamente a un proceso de "contrainfiltración" son destinados a realizar cursos para Tropas Especiales de Agitación que se realizan en centros de instrucción sitos en MEJICO DF, CUERNAVACA, TAXCO y en otro lugar aún no determinado. Los que reúnen aptitudes necesarias son destinados a efectuar los cursos de Tropas Especiales de Infantería en los campos de adiestramiento en EL LÍBANO, juntamente con militantes de la OLP [Organización de Liberación Palestina]. ${ }^{20}$

Al menos tres cuestiones sobresalen en la cita previa. En primer lugar, la idea que se desprende del informe sobre el tipo de participación que tendría cada integrante de la Contraofensiva una vez que retornara al país es inexacta. Las TEA no constituían un campo de prueba ni un paso intermedio para el alistamiento en las TEI. Una

${ }^{20}$ DIPBA, Mesa “D(s)”, Actualización de la BDT Montoneros, enero de 1980, p. 205. 
hipótesis acerca del porqué de esta inexactitud podría ubicarse en las propias ideas de los productores del documento. Evidentemente, la práctica militar encarnada por los grupos de "infantería" era concebida como una forma más elevada de acción política que las tareas de propaganda. No obstante, e independientemente de la ponderación que cada militante hiciera al interior de la organización, Montoneros las había diseñado como dos especialidades simultáneas, complementarias e independientes entre sí. Y teniendo en cuenta que casi las tres cuartas partes de los retornados en el marco de las "Tropas Especiales" lo habían hecho en grupos de propaganda, no restan muchos argumentos para respaldar la concepción que reproduce el informe, al menos en este punto (Gillespie, 1998, p. 318).

En segunda instancia, el requisito del proceso de "contrainfiltración" -examen para saber si el interesado estaba colaborando con la dictadura-ilumina la desconexión que la mayoría de los militantes tenía con Montoneros. A la vez, podría ser interpretado como un indicio de los riesgos que conllevaba la publicidad de la convocatoria: de aquí la necesidad que tenía la organización de asegurarse que los participantes de la Contraofensiva no fuesen infiltrados que la pusieran en riesgo. Pero no sólo eso, también evidenciaba los rastros del temor que había dejado la "Operación México" en su intento de capturar a la Conducción Nacional (Confino, 2018c). Por último, la regularidad en el trato a los "opcionados" 21 que consigna el informe parecería implicar que, al menos, una parte considerable de los reclutados había hecho uso de la opción para exiliarse. Otro documento de inteligencia del Ejército, producido por su Quinto Cuerpo en octubre de 1980, respalda esta idea y brinda información muy puntillosa sobre las actividades de quienes habían accedido al derecho a opción. Ese nivel de detalle, sin dudas, confirma la eficacia del espionaje militar sobre Montoneros:

4. Consideraciones sobre opcionados de esta BDT [Montoneros] Del análisis de informaciones obtenidas sobre las actividades realizadas por los DDTT [delincuentes terroristas] pertenecientes a esta banda, se ha podido tomar conocimiento que:

a. De 278 DDTT detectados, beneficiados con el derecho de opción, 129 de ellos (46\%) han reiniciado sus actividades.

b. De ese 46\%, 63 DDTT, o sea el 23\% del total, ingresó al país cumpliendo directivas de la conducción de la BDT.

c. Solo 12 DDTT (4\%) se habrían desvinculado definitivamente de la organización.

d. La banda, sabiendo que los opcionados son su mejor fuente de reclutamiento en el exterior, ha destinado personal y otros recursos para atender y capacitar a los mismos.

En MADRID, a principios de 1980, constituyeron a tal efecto "la casa del opcionado". 22

${ }^{21}$ De acuerdo al artículo 23 de la Constitución Nacional, aquellos detenidos a disposición del Poder Ejecutivo Nacional sin causa ni proceso durante la vigencia del estado de sitio, podían obtener la libertad a cambio de su salida del país (Jensen, 2007, p. 23).

${ }^{22}$ Ejército Argentino, "Informe de Inteligencia Especial Nro. 02/80 Actualización de la situación de la 
Confino. El reclutamiento y entrenamiento para la contraofensiva (1978-1980). Reflexiones sobre la política y...

Cerca de trescientos militantes montoneros habrían accedido a la opción y más de sesenta habrían reingresado desde el extranjero siguiendo las indicaciones de la Conducción Nacional. Por lo pronto, Alberione, B.C. y H.D. pertenecieron a este grupo. Independientemente de la exactitud de los números que consigna el documento, y de otros datos que obligan a tomar con cautela la fuente -como la constitución de la "casa del opcionado"-, todo indica que la "opción" fue una de las vías concretas y prevalentes que tuvo el "exilio montonero" y que nutrió, en gran proporción, a los contingentes que integraron la Contraofensiva. ${ }^{23}$

El secreto que enmarcó la preparación de la estrategia implica, entre algunas de sus consecuencias para la investigación histórica, una carencia de fuentes específicas sobre el proceso de incorporación que tuvo lugar en la Ciudad de México. Aun así, y al igual que lo sucedido en Madrid, se podría conjeturar que la convocatoria también suscitó discordancias entre los exiliados (Bernetti \& Giardinelli, 2014 y Yankelevich, 2010). México fue uno de los destinos preponderantes del exilio argentino durante la dictadura y el principal bastión político de Montoneros en el exterior. Allí, la organización tenía un local partidario en el que funcionaba el Consejo Superior del MPM. También allí estuvo asentada parte de la Conducción Nacional que, luego de la "Operación México", se trasladó a La Habana, en enero de 1978. Podría presumirse, entonces, que la modalidad de incorporación a la Contraofensiva en México fue más orgánica que en Madrid. Quizás también haya sido más gradual. La ausencia de una reunión informativa en la Ciudad de México para todos los exiliados, como había sucedido en Madrid, y la existencia de un resorte institucional como la "Casa Montonera" a través del cual se hizo el enrolamiento permiten abonar la hipótesis de la organicidad en la conformación de los contingentes en ese país. ${ }^{24}$ Perdía, muchos años después, ratifica esta posibilidad,

BDT Montoneros", octubre de 1980, p. 3, en Peiró, C., "Archivos secretos de la dictadura revelan su alto conocimiento de los planes de Montoneros", Infobae, 11 de diciembre de 2016. Un acto administrativo del Ministerio del Interior consigna que para el período 1974-1982 hubo en Argentina 872 presos que hicieron uso de la "opción" para salir del país. Tomando en consideración el informe de inteligencia y este documento podría concluirse que los militantes montoneros pudieron haber representado un tercio de la totalidad de los opcionados en ese período (Fondo OEA ONU, Caja AH/0123). Agradezco a María Soledad Lastra haberme puesto en contacto con este documento.

${ }^{23}$ La bibliografía sobre la temática ha respaldado la idea de que quienes se alistaron para el retorno a Argentina durante la Contraofensiva desconocían, por haber estado en la cárcel en la Argentina y haber salido en opción al extranjero, la virulencia represiva de la última dictadura (Gasparini, 2005; Larraquy, 2006 y Zuker, 2010). De esta manera, fundamentaban en el desconocimiento la voluntad de los intervinientes. No obstante, no hay muchos argumentos para respaldar este desconocimiento. Si bien podría haber sido este el caso de algunos militantes, lo cierto es que en líneas generales estuvieron al tanto de la represión dictatorial.

${ }^{24}$ El testimonio que brinda Liliana Mazure al archivo documental Memoria Abierta -Mazure fue exiliada en México y convocada al retorno en el marco de la Contraofensiva- parecería sustentar la idea de un proceso gradual de varias reuniones: en primer lugar, porque refiere que la convocaron desde dos lugares distintos dentro del "montonerismo" y, en segundo lugar, porque sugiere que sus intercambios con Rodolfo Puiggrós acerca de la situación en la Argentina habrían desembocado en el pasaje a la Contraofensiva y, por ende, en el inicio de la convocatoria. Mazure no volvió más a la sede del MPM en México luego del brindis que se celebró por la condena a muerte a Galimberti luego de su alejamiento previo al inicio de la Contraofensiva. Retornó al país en 1983 con el grupo comandado por el otrora 
al sostener que "En México había más conocimiento y [la convocatoria] se hizo de otra manera, no se hizo en una charla pública, sino más bien en "partecitas"". ${ }^{25}$

A la luz de lo observado para el proceso de reclutamiento, es posible hacer una primera aproximación a la convocatoria y la composición del grupo para la Contraofensiva. La recepción del anuncio montonero en el exterior fue, en primer lugar, polémica. Muchos exiliados que habían dejado atrás el peligro de la militancia en el país consideraban inviables las estrategias político-militares. No querían volver a la Argentina y preferían, de continuar sus actividades, hacerlo a través de la defensa de los derechos humanos y la denuncia de la dictadura en los foros internacionales. Aun así, hubo militantes que permanecieron en el extranjero formando parte de las actividades humanitarias y denuncialistas sin que ello supusiera abandonar Montoneros.

La amplitud de la convocatoria por parte de la organización profundizó la heterogeneidad del contingente. El "secreto a voces" que implicó el llamado para la Contraofensiva reunió, además de los militantes orgánicos de Montoneros, a exiliados sin vinculación estable, ex presos "opcionados" y militantes que habían quedado desconectados en la Argentina y habían logrado llegar al extranjero a recibir los cursos de formación para volver al país. Muchos de los participantes no habían militado nunca en estructuras militares y sí, en cambio, en las denominadas "organizaciones de superficie”. H.D. lo había hecho en la Unión de Estudiantes Secundarios (UES) y B.C., en la Juventud Universitaria Peronista (JUP). En un contexto en el que la represión dictatorial había dañado y quebrado las relaciones entre los militantes en el país, Montoneros buscaría, mediante la experiencia del entrenamiento en común, reparar los lazos fragmentados.

\section{El disciplinamiento de la diferencia}

Una vez finalizado el reclutamiento, los militantes involucrados en el regreso fueron dispuestos por la organización en grupos de "agitación" y de "infantería". Los enrolados con centro en Madrid, en líneas generales, pasaron un mes en una casa en las afueras de la capital española, entrenándose mientras esperaban que se completase el grupo. Luego, culminaron su formación en El Líbano y Siria, donde Montoneros había trazado un acuerdo con Al Fatah, conducción de la Organización de Liberación Palestina (OLP) por aquellos años. Si bien las relaciones entre ambas organizaciones habían comenzado en 1973, se hicieron públicas recién en 1977, después de la "retirada al exterior" de Montoneros y de la reunión, con foto incluida, que mantuvieron Firmenich y Vaca Narvaja con Yasser Arafat, en Beirut.

En el marco de un acuerdo político de más largo aliento que incluía cooperación en cuestiones de documentación, logística y armas, Al Fatah ofreció campos de entrenamiento con sus respectivos instructores y armas soviéticas, mientras que Montoneros instaló una fábrica de explosivos plásticos y proveyó los técnicos químicos

Secretario Militar de la "Columna Norte" (Memoria Abierta, Testimonio de Liliana Mazure, Buenos Aires, 20 y 29 de junio de 2007).

${ }^{25}$ Roberto Perdía, entrevista con el autor, ob. cit. 
Confino. El reclutamiento y entrenamiento para la contraofensiva (1978-1980). Reflexiones sobre la política y...

para dirigirla (Gillespie, 1998; Larraquy, 2006 y Robledo, 2018). Los militantes entrenados en el territorio palestino ingresarían a la Argentina a mediados de 1979 y deberían atentar militarmente, como parte de su desempeño en los grupos de "infantería", contra los funcionarios económicos de la dictadura. Tanto en México como en España y Medio Oriente, no obstante, la preparación de diversos contingentes continuaría durante todo ese año (Astiz, 2005; Falcone, 2001 y Larraquy, 2006). Además, Montoneros había dispuesto hacia principios de 1979 el regreso de los primeros militantes de las TEA, frente al pronóstico de aumento de los conflictos sindicales en oposición a la política económica de Martínez de Hoz. ${ }^{26}$

H.D. recuerda cómo fue su incorporación a la Contraofensiva en Madrid. El militante que la había visitado luego de la reunión de febrero le había dejado la directiva de abordar un tren de cercanías rumbo a un pueblo en las afueras de la capital. Luego de un par de horas de viaje, H.D. arribó a la estación indicada. Allí la esperaba el "teniente montonero" Osvaldo Olmedo, instructor del contingente y futuro jefe de uno de los grupos TEI. Olmedo era el hermano de Carlos, uno de los fundadores de las Fuerzas Armadas Revolucionarias (FAR), y había llegado a Montoneros con la fusión entre ambas organizaciones en 1973. Luego de reconocerlo a la salida de la estación, H.D. abordó el vehículo que los esperaba y respetó la indicación de no mirar el camino por la ventanilla, manteniendo la cabeza gacha entre sus piernas. Para su propia seguridad, según las normas de la organización, no debía saber dónde se ubicaba la casa que sería sede de la instrucción. ${ }^{27}$

El pueblo al que habían llegado H.D. y Olmedo era Collado Villalba, municipio de la comunidad madrileña situado en el valle que rodea al río Guadarrama, a unos cuarenta kilómetros de la capital española. Así lo reconstruye B.C., que también entrenó allí:

En marzo del 79 concreto una cita desde Torrelodones, a 30 kilómetros de Madrid, en la Estación Atocha de Madrid, ya con un bolsito, preparado para incorporarme. La cita es con un compañero que no conozco, tengo sospechas que se llamaba "Alberto" [Manuel "Alberto" López ${ }^{28}$ ] que después fue jefe de uno de los grupos TEI, pero no lo sé. Y ahí me llevan en auto, me subo a un tren que me lleva a un pueblo pasando Torrelodones, vuelvo a pasar Torrelodones, y ahí me bajo en la estación de Villalba [...] me bajo del tren, me subo a un auto con los ojos cerrados y entro en un garaje en una casa y estoy un mes seguro conviviendo con un grupo en el que ya había gente cuando yo llego y después llega alguno más. ${ }^{29}$

\footnotetext{
${ }^{26}$ El "Comando Táctico Adelantado" iba a ser dirigido por Rodolfo Galimberti, que a poco de iniciar el retorno decidió romper con Montoneros, dando forma al Peronismo Montonero Auténico (PMA) en febrero de 1979 (Slipak, 2017). En ese mismo mes, las TEA I, al mando de Adolfo "Gerardo" Regino González, ingresaban al territorio argentino (Larraquy, 2006).

${ }^{27}$ H.D., entrevista con el autor, ob. cit.

${ }^{28}$ Zuker, ob. cit., pp. 206-215.

${ }^{29}$ B.C., entrevista con el autor, ob. cit.
} 
El camino de H.D. y B.C. fue similar. Luego de una segunda entrevista privada con Lewinger, ambos acordaron su incorporación y fueron llevados a una casona en Collado Villalba donde también entrenaron, entre otros, Ricardo Zuker, Orlando Ruiz y Victoria Dameri. ${ }^{30}$ Además de encontrarse en Madrid e instruirse juntos en El Líbano, H.D. y B.C. conformaron el mismo grupo TEI liderado por Olmedo. Salvo algunas excepciones, los integrantes del grupo TEI no se conocían de antes.

Los términos de la incorporación de los militantes podían no trascender la duración de la Contraofensiva, sobre todo para quienes no habían tenido vínculo previo y estable con Montoneros antes de ese momento. Al respecto, recuerda B.C.:

Participaba, sí, de encuentros más políticos y culturales y sociales que tenían que ver con esto de la denuncia y la actividad pública, pero no estaba orgánicamente incorporado, para nada. No tuve militancia orgánica con Montoneros en el exilio, sólo cuando decidí incorporarme a la Contraofensiva y eso fue un corte [...] Lo que sí estaba claro, se terminó de confirmar cuando ya me incorporo, es que era por un tiempo acotado. No era que te incorporabas y te ibas, era por la tarea, era una contratación de obra. ${ }^{31}$

Entre quienes se alistaron para regresar al país, algunos no tenían vínculo orgánico y eran, en algún punto, militantes "eventuales" del peronismo revolucionario. Ese "contrato por obra" que refiere B.C. puede ser indicativo del tipo de lazo que la cúpula de la organización constituía con quienes se incorporaban, que distaba bastante del que había caracterizado a la militancia montonera a lo largo de la década. El vínculo desarrollado para la Contraofensiva aparecía de manera puntual y por un tiempo determinado. Cuando finalizara la estrategia los militantes no orgánicos podrían, tal como efectivamente hicieron muchos de ellos, rever su vínculo con la organización. Si el llamado del MPM había invitado a participar "subordinadamente" a los militantes, las palabras de B.C. ratificaban dicha subordinación.

A diferencia de H.D., que llegó a la casona de Collado Villalba pocos días antes de partir hacia El Líbano, B.C. pasó un mes de formación política y "orden cerrado", que era una estructura de comportamientos militarizados análoga a la de un cuartel militar:

Era una estructura claramente militarizada. Estaba muy formalizado el trato, con consignas, con un orden del día, estaba todo compartimentado y eso no lo discutíamos, era así. Horario de lectura, de bañarse, de comer, rotatorio, la manera de dirigirse, ejercicios físicos. Ahi no hubo nada militar, nada, nada, ni un arma, nada, mientras estuvimos en España. ${ }^{32}$

\footnotetext{
${ }^{30}$ Otros participantes del curso fueron Alcira "Julia" Macchi, "Momo", Ángel "Enrique" Carabajal, "Marta", "Ani", Manuel "Fernando" Camiño, "Juan" y Matilde Adela "Marisa" Rodríguez. (B.C., entrevista con el autor, ob. cit. y H.D., entrevista con el autor, op. cit.)

${ }^{31}$ B. C., entrevista con el autor, ob. cit.

${ }^{32}$ B. C. El énfasis es del autor.
} 
Confino. El reclutamiento y entrenamiento para la contraofensiva (1978-1980). Reflexiones sobre la política y...

Para B.C., el entrenamiento constituía "una estructura militarizada" pero "nada militar", abocada a la formación política y a la interiorización de las normas de conducta que regían en Montoneros y que muchos de los integrantes desconocían. Así también lo define Jorge Falcone, que regresaría al país durante la segunda Contraofensiva. Para el ex militante de las TEA, el entrenamiento fue "una colimba nacional y popular". ${ }^{33}$ En todo caso, la preparación para la Contraofensiva evidenciaba cómo la concepción militar de la política montonera trascendía el uso de armas e impregnaba el resto de las actividades de los militantes. Tal como afirma Vera Carnovale (2011) para el Partido Revolucionario de los Trabajadores-Ejército Revolucionario del Pueblo (PRT-ERP), pero igualmente válido para el caso de Montoneros, el componente militar no debería ser visto como una ausencia de política sino, al contrario, como uno de los elementos constitutivos de su definición. ${ }^{34}$ No obstante, la "lucha armada", entendida como método para la consecución de fines políticos, generó una relación ambigua, y por momentos tensa y contradictoria, con la política que la contuvo. En el caso de los militantes de la Contraofensiva, el ideario militar que enmarcó su actividad política no implicó forzosamente la experiencia previa de la práctica armada. Por eso, el entrenamiento tenía entre sus principales fines la representación y restitución de un escenario bélico que permitiera tanto la iniciación como el fortalecimiento de la destreza militar.

Más allá de la férrea disciplina que imperó durante esta etapa del entrenamiento, la primera preocupación de Montoneros fue homogeneizar a quienes tenían detrás de sí experiencias distintas vinculadas a la militancia "de superficie", la cárcel legal y el exilio, entre las más comunes. Por ello, el manejo de las armas, que además estaban prohibidas en España, ${ }^{35}$ aparecía como secundario. Primero era necesario unificar las expectativas de quienes las usarían. Para tal fin, Montoneros elaboró un cronograma muy minucioso que recreaba una estructura de cuerpo armado y reponía la simbología militar característica de su accionar político. Si el enrolamiento se había ordenado en función de la tarea a realizar, el entrenamiento buscaba restituir la historicidad montonera que se expresaba, en este caso, en las normas y los símbolos que regían en la casa de Collado Villalba.

La experiencia del entrenamiento en España también fue conocida por las Fuerzas Armadas. Con algunas imprecisiones, el personal especializado del Ejército supo e informó el proceso de instrucción de los militantes montoneros. Las comunicaciones internas más detalladas, de enero de 1980, permiten pensar que la información a la que había accedido el régimen tenía dos orígenes. El primero, y del que ya no quedan dudas, es la infiltración que había sufrido Montoneros, que habilitó el espionaje casi en tiempo real por parte de los servicios de inteligencia de la dictadura. Pero el conocimiento de los militares también

\footnotetext{
33 Jorge Falcone, entrevista con el autor, op. cit.

${ }^{34}$ En palabras de Carnovale (2011: 94-95): “Ofrecer ambos términos ('política y violencia') como excluyentes implicaría postular que es posible una política sin violencia y una violencia sin marcas políticas. Dicho de otro modo, que la violencia, en tanto régimen de medios, puede independizarse de los fines políticos, al tiempo que estos pueden prescindir de medios violentos."

${ }^{35}$ Montoneros tenía un acuerdo con el gobierno español en ese sentido. Aun así, la primera etapa del entrenamiento fue en suelo madrileño (Roberto Perdía, entrevista con el autor, ob. cit.).
} 
podía proceder de la información extraída a través de los tormentos ilegales causados a los militantes secuestrados en el país durante la Contraofensiva de 1979.

La localidad de la Berzosa es el lugar donde la inteligencia militar sitúa uno de los cursos de preparación de las "tropas de agitación”. Ubicado a nueve kilómetros de Collado Villalba, el sitio podría ser la casona madrileña que efectivamente albergó a los militantes TEI. Esta incerteza, siempre en el terreno de las especulaciones, indicaría que los hechos fueron reconstruidos con posterioridad, lo que ampliaría las opciones de que la información proviniera de la tortura de los militantes. No obstante, considerando que la mayoría de los participantes de la Contraofensiva, en el mejor de los casos, no debía saber con precisión dónde se encontraba la casa, la hipótesis de la infiltración no debería rechazarse de plano. Con respecto al contenido del entrenamiento, el informe militar más detallado destaca la existencia de dos módulos de enseñanza, uno teórico y otro práctico. En el cronograma de actividades, sin embargo, figuran entremezcladas las propias de las TEA con aquellas específicas de las TEI. El módulo teórico alude al manejo del equipo de transmisión (RLTV) desde su instalación, sus componentes y los lugares óptimos para realizar las interferencias. El práctico, por su parte, se concentra en el mantenimiento del RLTV e incluye el ejercicio de una transmisión móvil y de otra fija, con la simulación de un "copamiento" del lugar escogido. ${ }^{36}$ Tal vez la ausencia de armas generó, para los productores del informe, la impresión de que el entrenamiento en España era de propaganda cuando, según los testimonios recogidos y la literatura específica sobre el tema, correspondió al período no armado de la instrucción de los futuros grupos de "infantería” (Larraquy, 2006; Zuker, 2010 y Robledo, 2018).

En México, los cursos impartidos sí fueron de propaganda, con lo cual la modalidad fue distinta. En primer lugar, el entrenamiento no tuvo dos etapas como el de las TEI, escalonado entre España y Medio Oriente, y se concentró en dos caserones, uno al norte de la Ciudad de México, cerca de San Miguel de Allende, y otro al sur de la capital, en la zona de Cuernavaca. ${ }^{37}$ En segundo lugar, quizás por la accesibilidad geográfica, los períodos de entrenamiento fueron más lábiles y difusos a lo largo de todo el año y se prolongaron hasta entrado 1980. Allí los militantes practicaron el manejo del aparato de interferencia y realizaron entrenamiento físico, formación política y orden cerrado, al igual que se hacía en Collado Villalba. Con respecto al uso de armas, las fuentes son contradictorias. Mientras que Falcone, integrante de la Contraofensiva de 1980, recuerda que eran de madera o de juguete ${ }^{38}$, Eduardo "Pelado" Astiz (2005, p. 12), participante durante el año previo y primo segundo del represor Alfredo, asegura que el gobierno mexicano permitió "armas [...] para uso exclusivo de entrenamiento" que él mismo se ocupó de devolver a la Ciudad de México. ${ }^{39}$ La primera hipótesis que podría

\footnotetext{
${ }^{36}$ DIPBA, Mesa “D(s)”, Actualización BDT Montoneros, enero de 1980, p. 136.

${ }^{37}$ El documento de inteligencia menciona la existencia de dos lugares más amén de las casas de Cuernavaca y San Miguel. Es probable que esos dos lugares hayan funcionado más como "base" de agrupamiento de militantes que como sedes del entrenamiento. Aun así, es complejo determinarlo puesto que los militantes llegaban con los ojos vendados a todas las sedes que Montoneros manejaba en México.

38 Jorge Falcone, entrevista con el autor, ob. cit.

${ }^{39}$ Astiz participó de las TEA y entrenó en México desde enero de 1979 durante los tres meses que duró el
} 
Confino. El reclutamiento y entrenamiento para la contraofensiva (1978-1980). Reflexiones sobre la política y...

establecerse, dado que Falcone y Astiz no compartieron el mismo año de preparación, es que quizás las armas que habían estado permitidas en 1979 ya no lo estuvieran al año siguiente. No obstante, "Yuyo", instructor del primer grupo de las TEA en México y muy cercano al grupo nucleado en torno a Rodolfo Galimberti, tiene otra interpretación:

Sé que [los dirigentes de Montoneros] desconfiaban, aunque eso no está explícito en ningún lado. Desconfiaban, se nota después en algunas cosas que leí, por ejemplo, en que nosotros no teníamos instrucción con armas y el otro grupo, el del Pelado [Eduardo] Astiz hacía práctica de armas y a nosotros se nos decía que no se podía para no enfrentarse con el gobierno mexicano y a ellos sí le daban "fierros" y municiones [...] Él cuenta todas las prácticas de tiro y nosotros nada. Nosotros nos fuimos "por izquierda" a un polígono civil mexicano donde nos prestaron armas y tiramos [...] Y teníamos una pistola de aire comprimido. Y hay una compañera que recuerda que teníamos una pistola 45 sin municiones. Yo no lo recuerdo, pero supongo que habremos hecho la instrucción con esa pistola [...]. Simultáneamente ellos [la Conducción Nacional] les daban armas a otros. ${ }^{40}$

Yuyo" había vuelto al país en 1978 para la "Campaña de Ofensiva Táctica" que Montoneros había realizado durante el Mundial de fútbol disputado en la Argentina (Baschetti, 2014). Era muy cercano a Galimberti. En febrero de 1979 junto a Juan Gelman, Galimberti había publicado un comunicado de ruptura con el que confirmaba su alejamiento de la organización. En el testimonio de "Yuyo", esta situación es la que explica la desconfianza que atribuye a la Conducción Nacional. Allí ubica el motivo del trato diferenciado que recibió su grupo con respecto al obtenido por las TEA II, en el que participó Astiz. En su perspectiva, el armamento habría sido una prenda de cambio hacia los militantes "más leales" y no una norma explícita justificada en un arreglo político entre Montoneros y el gobierno mexicano.

Con todo, las armas no parecerían haber sido la prioridad de la organización en México. Tal como recuerda Astiz, el entrenamiento de su grupo duró tres meses y sus tareas trascendieron con holgura las habilidades militares. Entre ellas, sobresalen el "adoctrinamiento", la "discusión política", la "consolidación ideológica", todas actividades que evidenciaban la intención de Montoneros de homogeneizar y disciplinar las experiencias y expectativas de los integrantes de las futuras TEA (Astiz, 2005, p. 16). Pero no por ello el componente militar estuvo ausente. La "instrucción militar" y "práctica de combate" también formaron parte del cronograma de entrenamiento. La concepción militar de la política montonera trascendía, stricto sensu, la práctica armada.

curso. A diferencia de otros reclutados, tenía lazo orgánico con Montoneros, donde se había desempeñado como integrante de las "Tropas Especiales de Combate" que custodiaban a la Conducción Nacional antes de integrarse a la Contraofensiva.

40 "Yuyo", entrevista con el autor, Buenos Aires, 6 de enero de 2017. 
El dispositivo de disciplinamiento montonero cobraba sentido en virtud de las distintas procedencias y extracciones de los militantes alistados para la Contraofensiva. Baste como ejemplo el recuerdo de Falcone (2001, pp. 156-157) sobre su entrenamiento previo a la segunda Contraofensiva. En el "cuartel" montonero que integró se organizaron tres grupos. Entre sus participantes había militantes orgánicos pero también "de superficie" e, incluso, algunos sin historia previa al interior de la agrupación. Falcone, que se había desempeñado en la Secretaría de Prensa del Área Federal, remarca que varios de sus compañeros no poseían ligazón estable con la organización y el entrenamiento tenía en cuenta esta característica:

La rutina comenzaba a las seis de la mañana con formación, arenga y actividad gimnástica [...] Por la tarde habría un momento de descanso y esparcimiento en la piscina del parque. Más tarde, orden cerrado, instrucción militar y discusión política sobre la realidad de nuestro país. Por último, cena, lectura optativa y descanso [...] Como era costumbre en cada formación matinal, nos turnábamos para evocar a algún mártir de la causa (Falcone, 2001, p. 157).

Evidentemente, había una voluntad por parte de la organización de reponer los principales símbolos y sentidos que había traído aparejada la historia de la "lucha montonera". La evocación de los "mártires de la causa", al gestar un linaje militante y revolucionario con el cual identificarse, ejemplificaba esa intención. Así, el recuerdo institucional y organizado de la experiencia montonera se constituía simultáneamente en mito y arquetipo ya que recreaba el pasado para proyectarse hacia el futuro (Campos, 2016, p. 127). Al mismo tiempo que se exaltaban las historias de militancia consideradas íntegras desde los estándares políticos de la organización, se pretendía la emulación de dicho comportamiento en el futuro por parte de los militantes que regresarían a la Argentina.

Donde la práctica militar sí tuvo su principal expresión fue en El Líbano y Siria, sedes del entrenamiento de "infantería" que había comenzado en España. En las tres bases designadas por la organización, dos en El Líbano y una en Siria, los integrantes de las futuras TEI se prepararon aproximadamente durante noventa días. Damour, ciudad libanesa ubicada en la costa mediterránea, sería el destino escogido por Montoneros para el adiestramiento de las TEI II -integradas por H.D. y B.C.-. En Sidón, tercera ciudad de El Líbano y también lindante con el mar Mediterráneo, entrenarían las TEI I. Las TEI III, finalmente, harían lo propio en Siria, en un "destacamento" situado en las cercanías de Damasco. ${ }^{41}$ En todo momento, estarían apadrinados y acompañados por instructores de Al Fatah:

\footnotetext{
${ }^{41}$ En Damasco, según el testimonio de B.I., integrante del grupo III de las TEI, permanecían armados pero no utilizaban las armas porque estaban en un lugar poblado. Para la instrucción militar se trasladaban hacia el destacamento que quedaba en el "Monte" donde también se instruía el Ejército Sirio. Durante el entrenamiento, hubo instrucción física por la mañana muy temprano, luego teórica y por la tarde charlas y discusión política. Concluían el día con instrucciones de movimientos de combate en grupo (con armas,
} 
Confino. El reclutamiento y entrenamiento para la contraofensiva (1978-1980). Reflexiones sobre la política y...

\begin{abstract}
Había una base de la "orga" [Montoneros] allá. El vínculo era con Fatah y Fatah en ese momento era la conducción de la OLP. No tuve trato, pero concretamente llegamos a una zona que, como en toda situación de guerra, estaba dividida llena de controles. Te controlaban los pro-sirios, los pro-palestinos, los cascos azules de la ONU. Hasta que entramos a un barrio que era de la OLP [...] Estuvimos en una oficina una noche y al otro día nos llevaron a una casita en un pueblito de playa y montaña. Una casa tomada, destruida, abandonada. Era un pueblo que habían tomado los palestinos y era una villa, era como que nos fuéramos a vivir a una villa. Una villa asentada en casas tomadas. Y ahí me volví a encontrar con todos los que estaban en Madrid: me encontré con "Miguel" [Osvaldo Olmedo] y con todos los del grupo TEI I. Estábamos todos ahí y la relación de orden militar era con nuestro jefe, pero teníamos que responder a un responsable palestino que estaba todo el tiempo con nosotros [...] De alguna manera funcionaron como instructores y eran los que nos proveían de logística, autos, armas, explosivos. ${ }^{42}$
\end{abstract}

La situación atravesada por B.C. en El Líbano resultaba bastante disímil de la que debería transitar en la Argentina. Además del alojamiento, el acuerdo que Montoneros había trazado con Al Fatah contemplaba que la organización palestina se hiciera cargo de la formación teórica sobre el uso de armas y proveyera los medios necesarios para la realización del adiestramiento. Como ya referí, Montoneros, como contrapartida, montó una fábrica de explosivos plásticos en territorio palestino y envió a los especialistas necesarios para su fabricación. "Fuimos a El Líbano a aprender a tirar" 43 señala B.C., que nunca había portado ni disparado un arma en su vida. Tampoco lo había hecho H.D. ni muchos otros de sus compañeros. Por esta razón, la cúpula de la organización había elegido para el entrenamiento militar un territorio asolado por la guerra: los militantes deberían familiarizarse con la portación y el uso de armas de fuego, dormir y comer en condiciones precarias y sentir el rigor de la situación bélica. La Conducción Nacional pensaba que de este modo los montoneros estarían mejor preparados para afrontar el contexto clandestinidad que los esperaba en la Argentina.

No obstante, había ciertos lugares donde el dispositivo homogeneizador evidentemente no podía llegar:

Estábamos todos en la misma película. Lo que pasa es que en una estructura operativa tan ligada a la acción armada estaba toda esta cosa de homogeneizar distintos niveles de experiencia, de militancia y de extracción, pero lo común era el entrenamiento militar. Entonces eso tenía un límite, porque ahí

pero sin disparos) (B.I., correo electrónico intercambiado con el autor, diciembre de 2016).

${ }^{42}$ B.C., entrevista con el autor, ob. cit.

${ }^{43}$ B.C., entrevista con el autor, ob. cit. 
es muy difícil homogeneizar si es una cosa tan técnica. Tenés que aprender a jugar al básquet, y están los gordos, flacos, petisos, etcétera. Era técnica la cuestión.

Estaba lo otro como objetivo de rejuntar diferentes militancias y homogeneizarlas y creo que eso sí se consiguió, para mi ahí éramos todos iguales. Otra cosa es a la hora de lo específico que tenía que ver con la operativa de lo militar, que se notaban muchas diferencias en experiencia, por ejemplo. Yo no había estado "enfierrado" nunca en la Argentina, otros compañeros sí. ${ }^{44}$

Para B.C., la cuestión militar era una destreza técnica poco apta para ser aprendida en tiempos cortos y por esa razón quedaba estrechamente vinculada con las experiencias previas de los militantes. Desde su perspectiva, no podría haber nivelación posible teniendo en cuenta la magnitud de las diferencias al interior del contingente y la especificidad de la práctica que se intentaba enseñar. ${ }^{45}$ B.C., que provenía de la JUP, no tenía conocimientos al respecto. Pero incluso reconociendo esta limitación, destaca la efectividad del entrenamiento de un modo más general, en la nivelación de las distintas trayectorias políticas. En su testimonio, lo militar no aparece vinculado a las características generales de la militancia sino, por el contrario, homologado a una experiencia concreta y a una capacidad técnica.

La cotidianeidad del entrenamiento era muy exigente. Los militantes solamente tenían programado descanso los días domingo y el resto de la semana entrenaban en doble turno:

Nos levantábamos a las siete de la mañana, tomábamos mate cocido solo, parados, y con pan [...] Y ya a partir de ahí, salir. Entrenábamos en la playa que, digamos, era muy ancha y no había nadie. Teníamos que cruzar casi todo el pueblo hasta bajar a la playa. Íbamos obviamente en formación y corriendo. [...] Y en la playa bueno, era formación de ejercicios, copamiento, tiro al blanco [...] entrenábamos desde las ocho de la mañana hasta las doce, doce y media, volvíamos al pueblo, comíamos, se descansaba dos horas, tres, vuelta otra vez a la playa hasta las siete, ocho de la noche. ${ }^{46}$

\footnotetext{
${ }^{44}$ B.C., entrevista con el autor, ob. cit.

${ }^{45}$ Víctor Hugo "Beto" Díaz, jefe del grupo TEA-Sur, también se refiere a la preparación militar y, a la inversa de lo que estima B.C., apunta que las dificultades no son técnicas sino, al contrario, las que derivan del contexto político de la Argentina de la dictadura: "Aprender lo técnico de cómo se utiliza armamento, de cómo se dispone en un móvil, eso más o menos lo podes hacer, lo practicas varias veces. El tema pasa por otro lado, por conocer lo que nosotros llegamos a conocer, el territorio porque vivíamos acá. Conocíamos las calles, conocíamos todo y después cuando le desculas cómo pelea la dictadura y cómo peleamos nosotros; cuáles son nuestras armas y cuáles son las de ellos. Y el hecho de estar en combate, en una cosa, por ahí gente que no ha estado nunca y cuando empiezan los tiros te desequilibra y cuando aprendes a pelearle pueden sonar los tiros que vos estás viendo otro tipo de cosa." (Víctor Hugo Díaz, entrevista con el autor, La Plata, 27 de diciembre de 2016).

${ }^{46}$ H.D., entrevista con el autor, ob. cit.
} 
Confino. El reclutamiento y entrenamiento para la contraofensiva (1978-1980). Reflexiones sobre la política y...

La costa mediterránea libanesa fue el escenario donde los militantes entrenaron sus habilidades militares. Allí, la preparación contaba con muchas de las normas tradicionales de la guerra, como el uniforme y la formación. El grupo, que estaba acompañado por los palestinos e instruido por sus propios jefes, se confundía entre la situación bélica de Medio Oriente. Esa participación contrastaba, ciertamente, con el secreto con que deberían resguardar sus movimientos en el país. La instrucción serviría para que los jefes de los grupos TEI pudieran examinar las aptitudes de los militantes que integrarían los contingentes. De ellas dependería el tipo de actividad que les sería encargada una vez en la Argentina.

Si los servicios de inteligencia de la dictadura conocieron la instrucción montonera en México y España, Medio Oriente no fue la excepción. Una hipótesis sobre el origen de la información militar indica que los datos fueron obtenidos de una conferencia de prensa que había brindado, en septiembre de 1978, Mendizábal en Beirut junto con Abu Hatem, secretario de Relaciones Exteriores de Al Fatah, sobre el acuerdo entre Montoneros y la OLP, recogidos posteriormente por la revista española Cambio16. A partir del momento de la publicación de la noticia, los israelíes bombardearon El Líbano con el fin de atacar la fábrica de explosivos. No tuvieron éxito. Tal vez el personal de inteligencia israelí haya colaborado con el de la dictadura argentina intercambiando información sobre los montoneros en Medio Oriente (Larraquy, 2006; Lutzky, 2012 y Robledo, 2018):

[El curso] Comenzó desarrollándose en DAMUR [sic], en una casa semidestruída por los bombardeos israelitas, trasladándose a los quince días aproximadamente al sur de SAIDA [Sidón]. Los DDTT eran recibidos en el aeropuerto de BEIRUT y trasladados directamente al lugar donde se desarrollaba el curso. ${ }^{47}$

El movimiento que registran los servicios de inteligencia entre Damour, sede de adiestramiento de las TEI II, y Sidón, donde entrenaron las TEI I, no parecería haber ocurrido. La confusión podría obedecer a la presencia de militantes montoneros en ambas zonas y, también, a que durante el entrenamiento hubo tres militantes que fueron trasladados de un grupo al otro. ${ }^{48}$ Además, Damour fue efectivamente atacada y los militantes debieron cambiar de asentamiento durante el transcurso de los bombardeos, aunque no se trasladaron a Sidón. Incluso con estas salvedades, el documento era muy preciso en el detalle del cronograma de actividades:

0400 hs se levantaban, tenían 15 minutos para asearse, 15 minutos de gimnasia, 60 minutos de orden cerrado, luego desayuno, clases teóricas y prácticas hasta el almuerzo, luego descanso de una hora donde podían dormir y posteriormente clases teórico-prácticas hasta las 1915 horas. Volvían a formar a la noche y cubrían guardia de una hora cada uno, armados con fusil en posición de cuerpo a tierra o sentado. ${ }^{49}$

\footnotetext{
${ }^{47}$ DIPBA, Mesa “D(s)”, Actualización de la BDT Montoneros., enero de 1980, p. 138.

${ }^{48}$ H.D., entrevista con el autor, ob. cit.

${ }^{49}$ DIPBA, Mesa “D(s)”, Actualización de la BDT Montoneros., enero de 1980, p. 138.
} 
Salvo alguna diferencia en los horarios y en la denominación de las tareas, la información resulta muy consistente con la recordada por H.D. Incluso, el documento reservado hace referencia a los paseos que realizaban los militantes los domingos, único día libre que dispusieron durante la instrucción. Con respecto al contenido, e independientemente de que el entrenamiento en Medio Oriente giró en torno a la cuestión militar, también hubo formación política y discusiones en las que se manifestaron diferencias al interior del grupo sobre las características de las actividades a realizar. En una de esas charlas, en ocasión de una misa ofrecida por el capellán de la organización, el cura Jorge Adur ${ }^{50}$, B.C. tuvo una discusión con I.Q., "Alcides”, coordinador de los grupos TEI:

Esa fue una de las discusiones fuertes que yo tuve en El Líbano. Di esta discusión en El Líbano, la di. No es que la di después cuando me "abrí". Yo la di ahí: "somos unos marcianos", estamos haciendo cosas que no hace nadie, que no hace la gente. Y eso nos está aislando cada vez más. Y no es que estaba en desacuerdo, pero era plantear una cosa que se podía tomar como "bueno, vos porque te querés ir con tu mujer y tus hijos a comer asado". Sí, también. Pero era algo de que estábamos aislados y separados. Y la respuesta que tuve no podía ser menos. Fue en la misa con Adur y "Alcides", la respuesta fue justamente por el lado del sacrificio: "Es que tenemos compañeros presos, tenemos compañeros muertos". Eso era lo que me había llevado a mí a la Contraofensiva, eso ya lo sabía, a mí no me sirve, si yo me movilicé por eso. Yo, blanquito burgués, qué necesidad tenía, si hacía la carrera de médico tenía cinco mil hectáreas de campo, me chupa un huevo. Entonces qué me vas a contar, por supuesto que yo no salí por mí. El sacrificio sí, el que hicimos, pero esto ya no es sacrificio, es otra cosa. Es una discusión que di en El Líbano y me tiraron con los presos y los muertos. Y ahí, si te tiran con eso, sí, te callás. ${ }^{51}$

Mientras lo familiarizaba con la práctica militar, la experiencia de B.C. en El Líbano lo había vuelto crítico con las concepciones políticas de la organización. En su visión, la preparación militar los había alejado del resto de la sociedad argentina al sumergirlos en actividades exclusivas de difícil imitación y acompañamiento. Este argumento era coherente con su definición de la práctica armada: B.C. no la entendía solamente como una metodología asociada a la acción política -como sostenían los documentos partidarios-, sino también como una destreza particular y técnica muy

\footnotetext{
${ }^{50}$ El sacerdote Jorge Adur fue uno de los fundadores del Movimiento de Sacerdotes por el Tercer Mundo (MSTM) y desde julio de 1978, Capellán del Ejército Montonero. Fue secuestrado en junio de 1980, en el marco de la segunda Contraofensiva (elaboración propia en base a la biografía realizada por Roberto Baschetti, disponible en http://www.robertobaschetti.com/biografia/a/36.html ).

${ }^{51}$ B.C., entrevista con el autor, ob. cit.
} 
Confino. El reclutamiento y entrenamiento para la contraofensiva (1978-1980). Reflexiones sobre la política y...

difícil de aprender. Por otra parte, las razones esgrimidas por I.Q. coincidían con uno de los motivos principales del alistamiento de los militantes a la Contraofensiva: la cantidad de montoneros que habían sido víctimas de la represión en la Argentina. Además de ser uno de los móviles efectivos de la incorporación, el sentimiento de culpa por quienes habían sido secuestrados por el régimen de facto podía ser un argumento suficiente para resolver una discrepancia política.

Por otra parte, el fragmento resulta ilustrativo del imaginario sacrificial que imbuía la política montonera y que numerosos trabajos han privilegiado como objeto de estudio en sus acercamientos a las experiencias militantes de la década del setenta (Bufano, 2005; Carnovale, 2011; Longoni, 2007; Slipak, 2015 y Vezzetti, 2009). No obstante, la consideración de dicho imaginario sin su anclaje histórico y concreto -que proponga distinciones entre las organizaciones, los períodos e incluso los militantespuede contribuir a simplificar una trama histórica heterogénea y compleja de la que "el sacrificio" ciertamente formó parte pero no fue necesariamente su único o principal determinante. Por ejemplo, Sergio Bufano (2005, pp. 22-23) puntualiza sobre las causas que motivaron el regreso de los militantes para la Contraofensiva y destaca "la fascinación por la clandestinidad", "el deseo de reintegrarse a la acción por la acción misma" y "recuperar el brillo por la emoción de guerra", entre otros. Esa pulsión militar, referida también por Hugo Vezzetti (2009), no hace justicia a la heterogeneidad y complejidad que manifestó el proceso de incorporación a la Contraofensiva. Baste con señalar, entre otros matices, que muchos de los retornados nunca habían estado armados en el país y que la clandestinidad ha sido recordada más con pesar, miedo e incertidumbre que con deseo y fascinación (Zuker, 2010). En este sentido, el caso de B.C. es indicativo de las diversas apropiaciones que los actores hicieron del "mandato sacrificial" (Longoni, 2007).

Hacia el final del entrenamiento, la Conducción Nacional viajó a El Líbano y visitó el campamento de Damour. Para muchos de los militantes que allí se encontraban, era la primera vez que veían a los miembros más prominentes de la organización. Firmenich, Vaca Narvaja y Yäger acudieron al campamento de adiestramiento y presenciaron un simulacro de la toma de una supuesta comisaría con fuego real y luego hicieron un balance político de la medida y una comida de camaradería en la que insistieron con su diagnóstico de la realidad argentina y la tarea que tendrían a su cargo los contingentes de "infantería". También buscaron infundir ánimos en aquellos que transmitirían las propuestas montoneras en el país. Quienes se dirigían a la Argentina aún no sabían a ciencia cierta cuál iba a ser su misión, se enterarían una vez en el país. Firmenich y Vaca Narvaja permanecieron un día en Damour y luego partieron. Yäger, jefe de las TEI, se quedó un tiempo más para compaginar la modalidad de regreso con los jefes de los grupos. La etapa del entrenamiento para la Contraofensiva había concluido.

\section{Conclusiones}

Karl Schmitt ([1963] 2005: 23 y 24) señala el elevado grado de cohesión que los partidos revolucionarios promueven entre sus integrantes. ${ }^{52}$ El jurista y filósofo

\footnotetext{
52 "En la guerra revolucionaria la adhesión a un partido revolucionario implica nada menos que la
} 
alemán se refiere a una "captación total". Captación que, no obstante, y de acuerdo con lo analizado en estas páginas para el caso de Montoneros, no llegó a ser absoluta. El dispositivo homogeneizador y disciplinador montonero pudo haber funcionado poniendo en común las experiencias previas de los distintos integrantes, pero también causó resquemores entre algunos de ellos.

Un importante número de los que volvieron durante la Contraofensiva no tenían vínculo estable con la organización. Algunos habían militado en las llamadas "agrupaciones de superficie" de Montoneros pero no habían llegado a incorporarse a la estructura militar. Otros, los menos, no tenían ningún pasado que los vinculase a la organización, pero eso no había sido obstáculo para que decidieran regresar al país. Por último, volvieron montoneros orgánicos, algunos de los cuales habían tenido voz y voto en el lanzamiento de la Contraofensiva. Fue, en el intento de cohesión que persiguió la organización entre sus militantes, que la fase de instrucción adquirió sentido.

En los dos lugares principales del reclutamiento se dieron distintas dinámicas de incorporación. Mientras que en Madrid hubo una reunión informativa para atraer a los exiliados que se encontraban en Europa y no tenían vínculo estable con Montoneros, en la Ciudad de México el proceso fue más gradual. Y, también, más secreto. Por lo general, los convocados en España y otros países europeos entrenaron un mes en las afueras de Madrid y luego partieron a El Líbano y Siria a completar la formación militar. Los enrolados en México conformaron, en su mayor parte, los grupos de "agitación" que habían entrenado en Cuernavaca y San Miguel de Allende, en las afueras de la Ciudad de México. Sin embargo, y más allá de las precauciones tomadas por la organización, el llamado público realizado por el MPM fue imposible de compatibilizar con el secreto que necesitaba la Contraofensiva para ser efectiva y los servicios de inteligencia de la dictadura estuvieron al tanto de los preparativos montoneros.

Las características del dispositivo montado por la organización deben ser analizadas en virtud de la heterogeneidad de las trayectorias de quienes retornaron. Montoneros estructuró un entrenamiento integral que trascendió la habilidad militar y se extendió hacia la socialización de la simbología del imaginario bélico construida a lo largo de su historia. No obstante, el rescate del pasado no tenía una función meramente ilustrativa: al contrario, ese pasado "mítico" funcionaba también como modelo de conducta a ser imitado en el futuro. Además de la práctica armada, enfatizada para los grupos de "infantería", el entrenamiento contó con instancias de unión grupal que poco tuvieron que ver con las armas pero que son centrales en la autoconstrucción de un cuerpo militarizado: discusiones y arengas políticas, ratos de esparcimiento, formaciones e izamiento de bandera y recordatorios a los montoneros muertos, entre las más destacables. Por ello, sería impropio definir al entrenamiento como militarista si por ello se entiende estrictamente el uso de las armas de fuego o, también, el componente militar como antagónico al político. La lógica política y la militar no fueron, al menos en este caso, mutuamente excluyentes. En cambio, la concepción militar de la política

captación total. Otros grupos y organizaciones, sobre todo en el Estado actual, no consiguen integrar tan completamente a sus miembros y adheridos como un partido en lucha revolucionaria capta a sus combatientes activos.” (Schmitt, [1963] 2005: 24 y 25.). 
de Montoneros trascendió el uso de armamento y derramó su contenido sobre todas las actividades de la "fase de concentración". Ello no redundó en un vaciamiento de "lo político" como ha sostenido gran parte de la bibliografía que ha pensado la trayectoria de Montoneros en sus últimos años de existencia.

Militantes orgánicos e inorgánicos de Montoneros se unificaron ad hoc en el espacio político de la organización. A partir de su incorporación a la Contraofensiva devinieron, en mayor o menor medida, militantes montoneros al tanto de su historia y expectantes de su práctica futura. Les faltaba, por cierto, enfrentar el contexto represivo que la dictadura había alzado en el país.

\section{Referencias bibliográficas}

Acha, O. (2006). La nación futura. Rodolfo Puiggrós en las encrucijadas argentinas del Siglo XX. Buenos Aires: Eudeba.

Acha, O. (2010). "Dilemas de una violentología argentina: tiempos generacionales e ideologías en el debate sobre la historia reciente". V Jornadas de Trabajo sobre Historia Reciente, UNGS.

Agamben, G. (2011). “¿Qué es un dispositivo?”. Sociológica, 26, N 73, 249-264.

Astiz. E. (2005). Lo que mata de las balas es la velocidad: una historia de la contraofensiva montonera del 79. La Plata: De la Campana.

Baschetti, R. (2014). Documentos 78/80. Del Mundial a la Contraofensiva. La Plata: De la Campana.

Bernetti, J. \& Giardinelli, M. (2014). México: el exilio que hemos vivido. Memoria del exilio argentino en México durante la dictadura 1976-1983. Buenos Aires: Editorial Octubre.

Bufano, S. (2005). "La vida plena". Lucha Armada en la Argentina, 1.

Calveiro, P. (2005). Política y/o violencia. Una aproximación a la guerrilla de los años 70. Buenos Aires: Grupo Editorial Norma.

Campos, E. (2016). Cristianismo y revolución: el origen de Montoneros. Buenos Aires: Edhasa.

Carnovale, V. (2011). Los combatientes: historia del PRT-ERP. Buenos Aires: Siglo XXI.

Confino, H. (2018a). "Entre la articulación y el conflicto: una aproximación a los itinerarios de los exiliados montoneros en México". En Lastra, S. (comp.) Exilios: avances de un campo de investigación. Buenos Aires: CLACSO.

Confino, H. (2018b). "Volver sin haberse ido: el caso de las 'Tropas Especiales de Agitación Sur' durante la Contraofensiva. Revista Universitaria de Historia Militar, 14.

Confino, H. (2018c). La Contraofensiva Estratégica de Montoneros. Entre el exilio y la militancia revolucionaria (1976-1980). (Tesis de Doctorado). UNSAM, Buenos Aires.

Falcone, J. (2001). Memorial de guerralarga. Un pibe entre cientos de miles. La Plata: De la Campana. 
Franco, M. (2008). El exilio. Argentinos en Francia durante la dictadura. Buenos Aires: Siglo XXI.

Gago, V. (2012). Controversia: una lengua del exilio. Buenos Aires: Biblioteca Nacional. Gasparini, J. (2008). Montoneros. Final de cuentas. La Plata: De la Campana.

Gillespie, R. (1998). Soldados de Perón. Los Montoneros. Buenos Aires: Grijalbo.

Jensen, S. (2007). La provincia flotante. El exilio argentino en Cataluña (1976-2006). Barcelona: Fundació Casa Amèrica Catalunya.

Jensen, S. (2010). Los exiliados. La lucha por los derechos humanos durante la dictadura. Buenos Aires: Sudamericana.

Larraquy, M. (2006). Fuimos soldados. Historia secreta de la Contraofensiva montonera. Buenos Aires: Aguilar.

Longoni, A. (2007). ). Traiciones. La figura del traidor en los relatos acerca de los sobrevivientes de la represión. Buenos Aires: Grupo Editorial Norma.

Lutzky, D. (2012). Brindando sobre los escombros. Buenos Aires: Sudamericana.

Oberti, A. \& Pittaluga (2006). Memorias en montaje. Escrituras de la militancia y pensamientos sobre la historia. Buenos Aires: El Cielo por Asalto.

Ponza, P. (2010). "La izquierda en su laberinto: intelectuales argentinos, ideas y publicaciones en el exilio (1976-1983)". Boletín Americanista, 60, Barcelona.

Robledo, P. (2018). Montoneros y Palestina. Buenos Aires: Sudamericana.

Schmitt, K. ([1963] 2005). Teoría del partisano. Acotación al concepto de lo político. Buenos Aires: Editorial Struhart \& Cía.

Slipak, D. (2015). Las revistas montoneras. Cómo la organización construyó su identidad a través de sus publicaciones. Buenos Aires: Siglo XXI.

Slipak, D. (2017). "Sobre desvíos, espejos y cúpulas. Las disidencias montoneras y las lecturas sobre los años setenta". Revista Izquierdas, 32.

Vezzetti, H. (2009). Sobre la violencia revolucionaria: memorias y olvidos. Buenos Aires: Siglo XXI.

Yankelevich, P. (2010). Ráfagas de un exilio. Argentinos en México, 1974-1983. Buenos Aires: Fondo de Cultura Económica.

Zuker, C. (2010). El tren de la victoria. La saga de los Zuker. Buenos Aires: Del Nuevo Extremo.

\section{Entrevistas}

B.C. (2016). Entrevista con el autor, Buenos Aires.

B.I. (2016). Correo electrónico intercambiado con el autor.

Díaz, Víctor Hugo (2016). Entrevista con el autor, La Plata

Falcone, Jorge (2016). Entrevista con el autor, Buenos Aires.

H. D. (2015). Entrevista con el autor, Rosario.

H. N. (2016). Entrevista con el autor, Buenos Aires.

Perdía, Roberto (2016). Entrevista con el autor, City Bell.

"Yuyo" (2017). Entrevista con el autor, Buenos Aires.

Memoria Abierta, Testimonio de Elvio Alberione, Buenos Aires y Córdoba, 7 de junio y 4 de agosto de 2008 y 10 de diciembre de 2009. 
Memoria Abierta, Testimonio de Liliana Mazure, Buenos Aires, 20 y 29 de junio de 2007. Memoria Abierta, Testimonio de Juan Salinas, Buenos Aires, 6 y 11 de diciembre de 2002.

\section{Documentos}

DIPBA, Mesa "D(s)", Actualización de la BDT Montoneros, enero de 1980.

Ejército Argentino, "Informe de Inteligencia Especial Nro. 02/80 Actualización de la situación de la BDT Montoneros", octubre de 1980, p. 3, en Peiró, C., "Archivos secretos de la dictadura revelan su alto conocimiento de los planes de Montoneros", Infobae, 11 de diciembre de 2016.

Fondo OEA ONU, Caja AH/0123. 